\title{
Physical Test of Energy Saving Composite Board from Nipah Leaves nypa fruticans
}

\author{
Muhammad Arsyad 1,a,*, Muhammad Zakaria Umar ${ }^{1, b}$ and Mazhfia Umar,c, \\ ${ }^{1}$ Vocational Educational Program, Halu Oleo University, Kendari, Indonesia \\ ${ }^{2}$ Department of Forestry, College of Agricultural Sciences \\ a. email, b. email, c. email \\ *corresponding author
}

Keywords: $\quad$ Nipah leaves, composite material.

Abstract:Energy-saving architecture is based on the idea of minimizing energy use with science and cutting-edge technology. Nipah leaves is used as a composite material is one of the alternative use of energy-efficient building materials, available enough, and safe for the environment. This research is aimed to know the nipah leaf physical capability when it is done tensile test and bending test to composite material. Tensile and bending tests are the methods used in this study. Based on the result of the test on nipah composite material reinforced polyester resin concluded that the highest composite tensile strength on test specimen number (4) is $31.3073 \mathrm{~N} / \mathrm{mm}^{2}$. The lowest tensile stress on test specimen number (1) is $15.4616 \mathrm{~N} / \mathrm{mm}^{2}$. The greatest bending strength on test specimen number (2) is 3.3674 $\mathrm{N} / \mathrm{mm}^{2}$. The lowest bending stress on test specimen number (1) is $0.50372 \mathrm{~N} / \mathrm{mm}^{2}$. Composite board material made from nipah leaf has good tensile physical properties and bending is still needed the right mix formula.

\section{Introduction}

Environmentally friendly design concepts (Local wisdom) have been applied by our ancestors [1]. Energy-saving architecture is based on the idea of using minimal energy with advanced science and technology, for example the synergy between passive and active methods with optimal materials. The slogan of form follows function is shifted by energy conscious follows energy form [2]. Building elements such as walls directly or indirectly can be designed for energy savings with the selection of environmentally friendly materials [3]. Composite materials began to be widely used and developed in the world of manufacturing industry. Composite materials with natural fiber fillers and artificial fibers have been developed by the industrial world. Composite materials are environmentally friendly and can be recycled. Composite materials are two or more different materials that are combined into microscopic units. The composite material is made of various combinations of fibers and matrices. Currently composite materials reinforced with fiber engineering materials are widely used, because strength and stiffness are much better [4].

Renewable materials lead to vegetation-derived materials. Materials from vegetation can be utilized as raw materials for composite boards and are an alternative to mitigate negative 
environmental impacts. The use of this type of material is maintained in order to remain sustainable, then this type of material is highly recommended as a building builder [5]. In Kelurahan Petoaha, Abeli District, Kendari City is located Kampung KB (Family Planning). Kampung KB located on the location of coastal reclamation. Fathers in Kampung KB are busy as a fisherman. Mothers in Kampung KB are busy looking for metti-metti (Kalandoe/molusca bivalvia) and making roof material from nipah leaves. The leaves are derived from the nipah tree that grows around Kampung KB. The phenomenon in the field that so far only made nipah leaf roof. This phenomenon is captured and needed innovations other than the roof, resulting in a design that is energy efficient and is expected to increase revenue. One of the innovations to utilize nipah leaves is made of composite products such as boards. This research is aimed to know the physical resistance of composite board from nipah by doing tensile test and bending test

\section{Literature Review}

\subsection{Composite Board of Kinds of Palmae Plants}

Nipah (nypa fruticans) including family palmae. This plant grows in the brackish river water estuary [6]. Nipah forest area owned by Indonesia. The largest of the world's nipa palms around 17\% $(35,000,000$ hectares) is estimated to be in Indonesia. Nipah forest in Indonesia spread in Kalimantan, Sumatra, Sulawesi, Maluku, and Papua. The utilization of nipah tree is limited as roofing material and house wall [7]. Particle board made of palm leaves is one of innovations in the utilization of nipah leaf. The panel product is produced by compressing the particles of the material and simultaneously bonded with an adhesive called a particle board. Particle boards include composite products that are environmentally friendly, due to the raw materials of various wastes. Forestry, agricultural, plantation and household waste (used paper and plastic) are used as particle feedstocks. The result of description of physical and mechanical properties of particle board of nipah stalk that the test result of physics and mechanical test have fulfilled SNI standard (1996), except the standard of thickness test result is not fulfilled. Composite material from nipah leaf with $15 \%$ adhesive composition (A2B3), water content test result 8,088\%, density $0,725 \mathrm{~g} / \mathrm{cm} 3$, thickness $13,050 \%$, MoR 40,230 kg / cm2 and MoE $3781,390 \mathrm{~kg} / \mathrm{cm} 2$ including best category [8].

Sago deck is a type of palm tree that can be used as particle board. The result of descriptions of weathering that all samples of sago palm composite board can not withstand the attack of fungus and soil termites (c gestroi). The composite board treated with $12 \% \mathrm{PF}$ adhesive shows the best resistance to fungal attack [9]. The high dimensional stability is possessed by composite boards of coco fiber and polypropylene plastic (PP), but low flexural strength $(11400 \mathrm{~kg} / \mathrm{cm} 2)$. This is due to the low interphase between plastic and coconut husk [10]. The results of elastic modulus description show that the addition of maleic anhydride (MAH) of $6 \%$ and dicumyl peroxide (DCP) by $15 \%$ can increase the elasticity of composite board compared to composite board without the addition of DCP (8886 kg $/ \mathrm{cm} 2$ ) [11]. Thus it can be concluded that the type of palmea plants can be made particle board because the raw material is available and has been tested.

\subsection{Tensile Strength}

The mechanical properties are studied by observing the properties of tensile strength of the material. The mechanical properties are given pressure by using gauges. Tensile strength is defined as the resistance of a material that works in parallel so that the material is broken [12]. The resistance of materials that work in parallel so that the breaking material is called tensile strength. Tensile tests were performed with test specimens. The voltage is received from the center of the test bar. In this section the length of the test bar was measured. The data were obtained from the tensile test machine 
expressed by the graph. This graph can not be used yet, because the received style load only describes the ability of the test bar. To be used as a description of the nature of the material, it must be a tensile diagram. Data obtained from the pull diagram [13]. Tensile strength is measured by dividing the load value at the time the specimen is broken. The result of tensile strength is expressed in megapascals (MPa). Percent elongation is measured by dividing the value of the length change due to the tensile load. The calculation results are expressed in percent [14]. Thus it can be concluded that the tensile strength is defined as the resistance of the material working in parallel so that the material is broken. The tensile test is expressed in the graph and percent.

\subsection{Strong Bending}

The material's ability to withstand bending forces in the direction perpendicular to the crosssection is called bending strength [15]. Flexural testing is used to determine the ability of the board to withstand bending forces in the direction perpendicular to the cross section. The test was performed 3 times for each sample composition [16]. The ability of the board to hold the load to the limit of proportion is called bending firmness [17]. Thus, the flexural strength is defined as the material's ability to withstand bending forces in a direction perpendicular to the cross-section to the proportion limit.

\section{Research Method}

\subsection{Types of Research Methods}

Experimental methods of analysis were used in this study. Data obtained from testing. Data processed and drawn conclusions from the analysis that has been done. Data were collected from testing of composite materials. Data is carefully collected and recorded against the composite. Quantitative exploratory techniques are used in data analysis techniques to test results.

\subsection{Time, Place, Work tools, Work Materials, and How to Make}

This research will be conducted in Laboratory of Materials and Mechanical Technology, Department of Mechanical Engineering, Faculty of Engineering, Halu Oleo University, Kendari. Digital scales, composite molds, scooters, spoons, kater, brushes, putty knives, stationeries, and rulers are work tools used. Nipah leaves, polyster resin oil, mekpo hardener, and mirror glaze are the materials used. Composite materials are prepared in the following manner: 1) Work tools and materials prepared for composite making; 2) The volume fraction is determined according to the mixture to fill the composite mold; 3) Nipah leaves are stirred before coating with matrix; 4) After the material is well blended the printing process is done; 5) After the composite is printed, the composite is removed from the mold and the drying process is carried out.

\subsection{Creation of Test Specimens}

The composites are printed with prints measuring $190 \mathrm{~mm}$ in length, $30 \mathrm{~mm}$ in width, and $5 \mathrm{~mm}$ in height. The mold is made of glass and mashed with rubbing. Glass material is used to facilitate the printing process, because the glass has a smooth surface and easy to release the composite. Standard size used on the put in accordance with ASTM D 638-01 standard. The standard is a tensile test specimen. ASTMD 790-02 is used for bending test specimens with a total of 3 specimens for each treatment. In the final stages of specimen preparation, the process of smoothing test specimens to avoid failure. 


\subsection{Time, Place, Work tools, Work Materials, and How to Make}

This research is done by tensile and bending test. The tensile and bending test is performed, as follows: a) Universal Testing Simadzu brand is a machine used for tensile test. Load cell $1000 \mathrm{~kg}$ with a tensile speed of $10 \mathrm{~mm} / \mathrm{min}$ is the parameter used in the tensile test. The standard procedure ASTM D 638-01 is followed in tensile testing. Tensile test specimens were tested by the following steps: 1) Tensile test specimens prepared;2) The tensile test machine is activated;2) The specimen data is entered; 3) Tensile test specimens mounted on the tap and confirmed to be properly clamped; 4) The tensile test machine is run and the tensile test phenomenon is recorded on the CPU and is visible on the computer screen; 5) Automatically the machine stops after the specimen is broken and the test result data is stored on the computer; 6) Plotter machine recording results are taken from the process of withdrawal on the computer. Bending testing is done by giving the bending load slowly until the specimen reaches the point of fracture. The specimen is pressed on the upper bending test. The pull process is experienced by the lower specimen, so the specimen is broken at the bottom. The test specimens were made according to ASTM D709-02 standards. The bending test is performed on a tensile test machine. The bending test is carried out with the following steps: a) Bending test specimens are prepared; $b$ ) Bending testing machine prepared in active state; $b$ ) The specimen data is entered and the bending test machine program is prepared; c) Bending test machine installed; d) The bending test machine is activated and under these conditions the bending test phenomenon can be recorded on the CPU and visible on the computer screen; e) Once broken, the machine stops automatically and test data is stored in the CPU; f) Plotter machine recording results are taken from the pressing process.

\section{Result and Discussion}

\subsection{Tensile Tests}

The tensile strength of the nipah composite material given the polyster resin is known by tensile testing.

Table 1. Data of tensile test results on each composite

\begin{tabular}{|l|l|l|l|l|}
\hline \multirow{2}{*}{ Test objects } & \multicolumn{4}{|c|}{ Data of Pull Test Result } \\
\cline { 2 - 5 } & Max Force $(\boldsymbol{N})$ & Width $(\mathbf{m m})$ & Thickness $(\mathbf{m m})$ & Max Stress $(\mathbf{N} / \mathbf{m m})$ \\
\hline 1 & 1005.00 & 13.0000 & 5.0000 & 15.4616 \\
\hline 2 & 1723.04 & 13.0000 & 5.0000 & 26.5083 \\
\hline 3 & 1755.85 & 13.0000 & 5.0000 & 27.0130 \\
\hline 4 & 2034.97 & 13.0000 & 5.0000 & 31.3073 \\
\hline Average & 1629.715 & \multicolumn{4}{|l|}{} & 25.0726 \\
\hline SNI 2006 [18] & $0.3040 \mathrm{~N} / \mathrm{mm}^{2}$ & 25.0726 \\
\hline
\end{tabular}

Table 1 above is explained that the ratio of tensile stress received from each specimen. The amount of high tensile stress received by the composite material of the nipah leaf and reinforced with polyster resin is found on the specimen number 4 of $31.3073 \mathrm{~N} / \mathrm{mm}^{2}$. The lowest tensile stress on test specimen number 1 is $15.4616 \mathrm{~N} / \mathrm{mm}^{2}$. The average tensile stress of the composite material is $25.0726 \mathrm{~N} / \mathrm{mm}^{2}$ higher than the SNI tensile stress. All specimens are categorized better than SNI. It is shown that nipah composite material has good tensile strength. The tensile test results are seen in the Figure 1 which describes the specimen against the tensile strength of the composite leaf material of palm leaf. 
Figure 1 observed the difference in tensile strength on each specimen and mixed between the leaves of nipah with polyester resin. The tensile strength of each specimen because the nipah leaf material is reinforced with a polyster resin. The results of this test that the tensile strength of composite materials is influenced by nipah leaf material. When a good mixture is possessed by a composite material, a better bonding process is produced by a combination of palm leaves and polyester resin. Therefore, the breaking phenomenon is experienced by the composite in the tensile test before being able to receive a larger voltage.

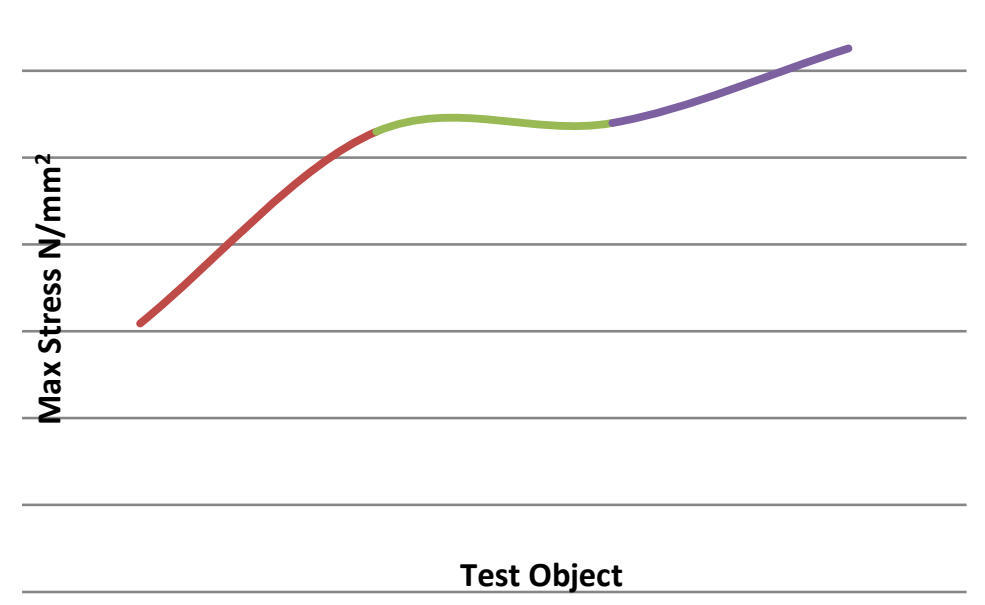

Figure 1. The differences in tensile strenght on each specimen and mixed between of nipah with polyster resin

\subsection{Bending Tests}

The mechanical testing of a composite material in receiving the compressive load is tested by bending test. In this test that the compressive loading of composite nipah compressed material with polyester resin.

Table 2. Data of bending test results on each composite.

\begin{tabular}{|l|l|l|l|l|}
\hline \multirow{2}{*}{ Test objects } & \multicolumn{5}{|c|}{ Data of Pull Test Result } \\
\cline { 2 - 6 } & Max Force (N) & Width $(\mathbf{m m})$ & Thickness $(\mathbf{m m})$ & $\begin{array}{c}\text { Max Stress } \\
\text { (N/mm2) }\end{array}$ \\
\hline 1 & 40.2975 & 16.0000 & 5.0000 & 0.50372 \\
\hline 2 & 269.394 & 16.0000 & 5.0000 & 3.36742 \\
\hline 3 & 123.789 & 16.0000 & 5.0000 & 1.54736 \\
\hline 4 & 189.927 & 16.0000 & 5.0000 & 2.37409 \\
\hline Average & 623.4075 & \multicolumn{5}{|l|}{} \\
\hline SNI 2006 [18] & $3.001 \mathrm{~N} / \mathrm{mm}^{2}$ & 1.9482 \\
\hline
\end{tabular}

Table 2 above explained that the comparison of bending voltages received from each specimen. The high bending voltage received by the composite material of the nipah leaf with reinforced polyster resin is found on test specimen number (2) of $3.36742 \mathrm{~N} / \mathrm{mm}^{2}$. The lowest bending stress on test specimen number (1) is $0.50372 \mathrm{~N} / \mathrm{mm}^{2}$. Bending stress of the test object No. 2 obtained higher than the SNI and other test objects obtained lower than the SNI.

The low strength of bending occurs due to the uneven distribution of nipah leaves in the matrix in the stirring process. Stirring is done manually, so the material mixture occurs void on the polyester 
resin. The strength of the composite to withstand the load of the bending depends on the retaining of the material movements, since in addition to the bending stress there is also tensile stress and the shear stress along the cross section of the composite. The nipah leaf is tied to the resin holding the shear, thus enlarging the bending strength of the composite. Composite failure begins when the deflection increases and the bending load reaches the maximum. The damaged composite at the top is due to the bending load. Then, the damage propagates to the left and right of the area and downward until loading is stopped on a certain deflection. This also occurs in the strength of composite bending developed with nipah filler. The nipah leaf composite is used to limit the movement of polyester matrix when the composite is given bending so that the strain is small.

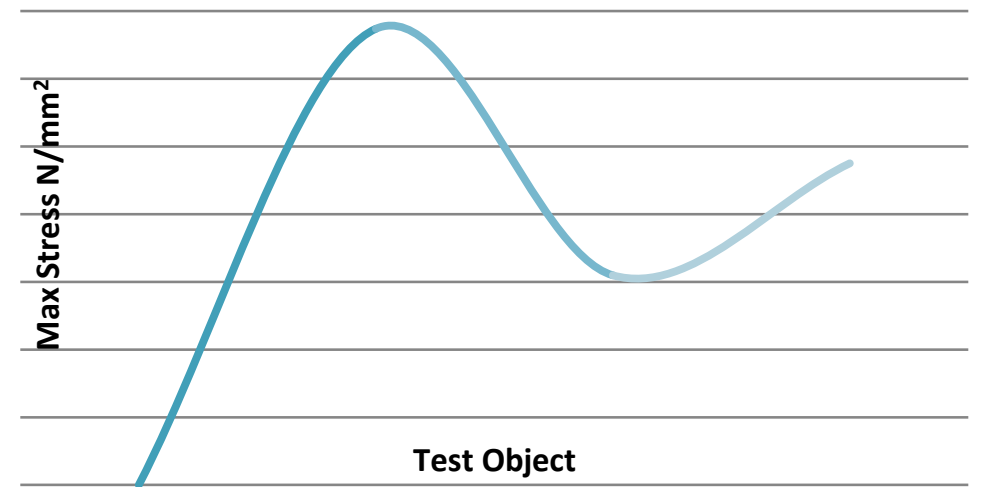

Figure 2. The differences in tensile strenght on each specimen and mixed between of nipah with polyster resin

Figure 2 above observed differences in bending strength on each specimen and mixed with nipah leaf and polyester resin. The tensile strength of $31.3073 \mathrm{~N} / \mathrm{mm}^{2}$ is owned by the test specimen number (4). The magnitude of the tensile strength belongs to the test specimen number (4) because the nipah leaf material is reinforced with a polyster resin. The results of this test that the tensile strength of composite materials is influenced by nipah leaf material. When a good mixture is possessed by a composite material, a better bonding process is produced by a combination of palm leaves and polyester resin. Therefore, the breaking phenomenon is experienced by the composite before being able to receive a larger voltage.
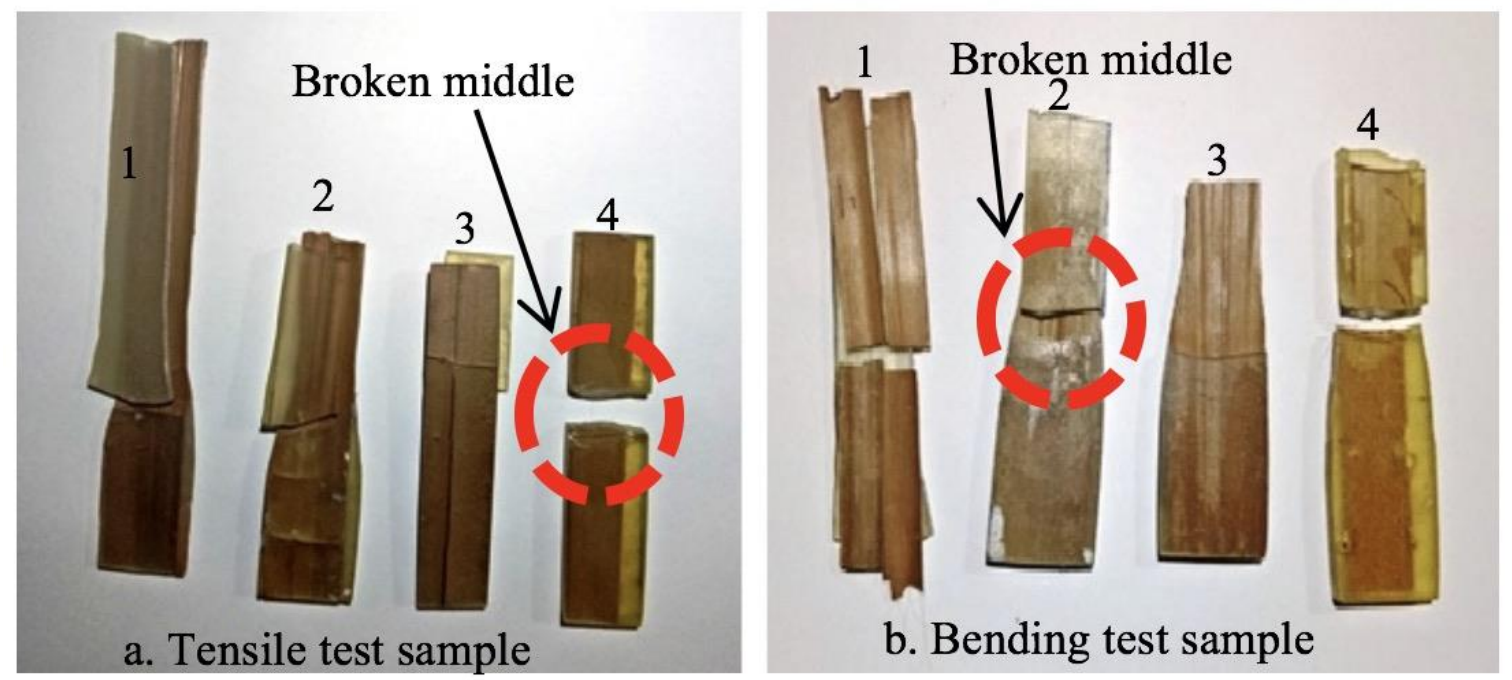

Figure 3. Tensile test sample and bending test sample 
The sample tensile test value of number 4 is higher than the other samples and is indicated by the middle fracture of the specimen (Figure 1a). The sample bending test value of number 2 is higher than the other samples and is shown with the middle fracture on the specimen (Figure 1b).

\section{Conclusion}

Based on the result of the test on nipah composite material reinforced polyester resin concluded that the highest composite tensile strength on test specimen number (4) is $31.3073 \mathrm{~N} / \mathrm{mm}^{2}$. The lowest tensile stress on test specimen number (1) is $15.4616 \mathrm{~N} / \mathrm{mm}^{2}$. The greatest bending strength on test specimen number (2) is $3.3674 \mathrm{~N} / \mathrm{mm}^{2}$. The lowest bending stress on test specimen number (1) is $0.50372 \mathrm{~N} / \mathrm{mm}^{2}$. Composite board material made from nipah leaf has good tensile physical properties and bending is still needed the right mix formula.

\section{References}

[1] E. Prianto, “Aplikasi Green Wall Pada Gedung Pemerintah Dalam Menciptakan Kenyamanan Di Kota Semarang: Sebuah Studi Awal,” J. Riptek, vol 7, p. 1-14, 2013.

[2] J. Priatman, “Energi-Efficient Architecture Paradigma dan Manifestasi Asritektur Hijau,' J. Dimensi Teknik Arsitektur, vol 30, p. 167-175, December 2002.

[3] J. Priatman, “Energy Conscious Design Konsepsi dan Strategi Perancangan Bangunan di Indonesia,” J. Dimensi Teknik Arsitektur, vol 31, p. 43-51, Juli 2003.

[4] S.A. Daulay, F. Wirathama, and Halimatuddahliana, "Pengaruh Ukuran Partikel dan Komposisi Terhadap Sifat Kekuatan Bentuk Komposit Epoksi Berpengisi Serat Daun Nanas, ”. J. Teknik Kimia USU, vol. 3, September, p. 13, September 2014.

[5] T.H. Karyono, Green Architecture Pengantar Pemahaman Arsitektur Hijau Di Indonesia, $1^{\text {st }}$ ed., PT RajaGrafindo Persada: Jakarta, 2010.

[6] Khalil and T. Hidayat, "Potensi Buah Nipah Tua (Nypa Fruticans Wurmb) Sebagai Bahan Pakan Ternak,” J. Peternakan Indonesia, vol. 11, p. 123-128, 2006.

[7] L.F. Yeni, A. Hidayat, and R. Marlina, "Isolasi dan Aktifitas Fermentasi Bakteri Asam Asetat pada Nira Nipah (Nypa fruticans)," J. Pendidikan Matematika dan IPA, vol 2, p 1-10, Januari 2011.

[8] F.T. Wulandari, Deskripsi Sifat Fisika dan Mekanika Papan Partikel Tangkai Daun Nipah (nypa fruticans. Wurmb) dan Papan Partikel Batang Bengle (Zingiber cassumunar. Roxb),”J. Media Bina Ilmiah, vol 6, p 7, 2012.

[9] D. Zulfiana, and S.S. Kusumah, "Ketahanan Papan Komposit dari Pelepah Sagu (Metroxylon sago Rottb.) Terhadap Jamur Pelapuk dan Rayap Tanah," J. Penelitian Hasil Hutan, vol 32, p. 253-262, December 2014.

[10]D. Setyawati, M.Y. Massijaya, Pengembangan Papan Komposit Berkualitas Tinggi dari Sabut Kelapa dan Plastik Polipropilena Daur Ulang (I): Suhu dan Waktu Kempa Panas, ” J. Teknologi Hasil Hutan, vol 18, p. 91 -101, 2005.

[11]A.H. Iswanto and F. Febrianto, "The Role Of Dicumyl Peroxide (Dcp) In The Strengthening Of Polymer Composites,” J. Peronema Forestry Science, vol.1, p. 46, September 2005.

[12]K.R. Midia, "Pemanfaatan Serat Daun Mengkuang (Pandanus Artocapus) Sebagai Bahan Baku Pembuatan Komposit," Under Graduate Thesis, p. 23, 2016.

[13]P.D. Setyawan, N.H. Sari, D.G.P. Putra, "Pengaruh Orientasi dan Fraksis Volume Serat Daun Nanas (Ananas Comous) Terhadap Kekuatan Tarik Komposit Polyester Tak Jenuh (Up)," J. Dinamika Teknik Mesin, vol 2, p. 2930, Januari 2012.

[14]S. Rohmah, R. Satoto, A. Suhandi, "Pengaruh Penambahan Limbahan Daun Sukun Terhadap Kekuatan Tarik dan Kekerasan Rockwell Komposit Pe/Daun," J. Fibusi (JoF), vol. 3, p. 4, December 2015. 